\title{
Lysimachia xiangxiensis (Primulaceae), a new species from limestone area in Hunan Province, central China
}

\author{
Cun Mou ${ }^{1,2,3^{*}}, \mathrm{Yu} \mathrm{Wu}^{4^{*}}$, Liang Xiang ${ }^{5}$, Xiao-Mei Xiang ${ }^{6}$, Dai-Gui Zhang ${ }^{6}$ \\ I Hunan Forest Botanical Garden, Changsha 410116, Hunan, China 2 Key Laboratory of Cultivation and \\ Protection for Non-Wood Forest Trees of Ministry of Education, Changsha 410004, Hunan, China 3 Key \\ Laboratory of Non-Wood Forest Product of State Forestry Administration, Central South University of Forestry \\ and Technology, Changsha 410004, Hunan, China 4 College of Life Sciences, Hunan Normal University, \\ Changsha 410081, Hunan, China 5 Jishou Dehang Scenic Area Management Office, Jishou 416000, Hunan, \\ China 6 College of Biology and Environmental Sciences, Jishou University, Jishou 416000, Hunan, China \\ Corresponding author: Dai-Gui Zhang (zdg634278@126.com)
}

Academic editor: Peter de Lange $\mid$ Received 4 November 2019| Accepted 12 December 2019| Published 24February 2020

Citation: Mou C, Wu Y, Xiang L, Xiang X-M, Zhang D-G (2020) Lysimachiaxiangxiensis (Primulaceae), a new species from limestone area in Hunan Province, central China. PhytoKeys 140: 23-32. https://doi.org/10.3897/phytokeys.140.47995

\begin{abstract}
A new species of Lysimachia, L. xiangxiensis (Primulaceae), is described and illustrated from western $\mathrm{Hu}$ nan, central China. The species is similar to L. melampyroides in plant densely strigillose, leaves subglabrous adaxially, and flowers usually solitary in axils of upper leaves, but differs by the succulent leaves, the creeping or ascending stems $15-25 \mathrm{~cm}$ long, and the suborbicular to broadly elliptic corolla lobes. This new species is also supported by a molecular phylogenetic analysis of some Lysimachia species based on ITS sequence data.
\end{abstract}

\section{Keywords}

Lysimachia, L. xiangxiensis, new species, taxonomy, western Hunan

\section{Introduction}

The genus Lysimachia L., a large genera of Primulaceae s. 1. (APG III 2009), consists of over 180 species of annual or perennial herbs (Hu and Kelso 1996). Lysimachia has a nearly cosmopolitan distribution, mainly occurring in the temperate and subtropi-

\footnotetext{
* These authors contributed equally to this work
}

Copyright Cun Mou et al. This is an open access article distributed under the terms of the Creative Commons Attribution License (CC BY 4.0), which permits unrestricted use, distribution, and reproduction in any medium, provided the original author and source are credited. 
cal parts of the northern hemisphere, with a few species in Africa, Australia and South America (Hu and Kelso 1996, Liu et al. 2014a). Southwestern China and its neighboring region of Indochina Peninsula have an extremely high species diversity with ca. 130 species and have been considered to be the diversity center of the genus (Yan et al. 2017).

During our expedition in 2017 and 2019 to the Youshui River valley in western Hunan, China, an unusual population of Lysimachia, with the plants having revolute succulent leaves, caught our attention. After consulting the relevant literature (Chen et al. 1989, Hu and Kelso 1996, Yan and Hao 2012, Liu et al. 2014a, Liu et al. 2014b, Zhou et al. 2015, Wang et al. 2018) and checking relevant specimens, we determined that the population represents a new species. Additionally, the new species is supported by a molecular phylogenetic analysis of some Lysimachia species based on ITS sequence data.

\section{Materials and methods}

\section{Taxon sampling and morphological analysis}

The type specimens and fresh materials of the new species were collected from $\mathrm{Hu}$ ayuan County and Jishou City, Hunan Province, central China. Morphological observations and measurements were randomly made on flowering and fruiting plants. We examined related specimens kept in JIU and HUN and also specimen images in the online database of Chinese Virtual Herbarium (http://www.cvh.ac.cn) and JSTOR Global Plants (https://plants.jstor.org).

A total of 39 nuclear ribosomal ITS sequences for 34 species (Appendix S1) were downloaded from GenBank, following a study of Lysimachia (Zhang et al. 2011, Zhou et al. 2015). Two accessions of the putatively new species were sequenced for this study (GenBank Acc. No.: MN647744, MN647745). Ardisia verbascifolia Mez was selected as outgroup following Zhang et al. (2011). Voucher specimens of those specimens of the new species used for sequencing were deposited in JIU.

\section{Molecular analyses}

Total genomic DNA of the two accessions of the putatively new species was isolated from silica gel-dried leaves using a modified cetyltrimethylammonium bromide procedure (Doyle and Doyle 1987). The ITS region was amplified and sequenced by method of Zhang et al. (2011).

Phylogenetic trees were constructed using maximum likelihood (ML) and Bayesian inference (BI). The models determined for the datasets using the Akaike information criterion (Burnham and Anderson 2003) as implemented in MrModeltest 2.3 (Nylander 2004). ML trees were generated in RAxML 7.2.6 (Stamatakis 2006) with 1000 bootstrap replicates. BI trees were inferred in MrBayes version 3.1.2 (Huelsen-

beck and Ronquist 2001). Four chains, each starting with a random tree, were run for 1,000,000 generations with trees sampled every 1000 generations. The convergence 
of the two runs was accessed with the average standard deviation of split frequencies less than 0.01 . After the first ca. 25\% discarded as burn-in, the remaining trees were imported into PAUP* v.4.0b10 (Swofford 2002) and a 50\% majority rule consensus tree was produced to obtain posterior probabilities (PP) of the clades.

\section{Results and discussion}

\section{Morphological comparisons}

According to the key in $\mathrm{Hu}$ and Kelso (1996), the new species is positioned to "Key 2" by flowers 5-merous, homomorphic, corolla yellow, anthers shorter than filaments, and further to "19a" by anthers distinctly dorsifixed (1b), inflorescences not paniculate(3b), stems more than $5 \mathrm{~cm}$ and leaves opposite (5b), corolla subfunnelform, filaments connate $1 / 3-1 / 2$ into a tube (7b), flowers axillary and solitary or in terminal clusters with bracts leaflike (12b), inflorescences not capitate (17a), leaf blade not connate-perfoliate (18b), flowers solitary and axillary or in terminal racemes, plants strigillose (19a).

Morphologically, the new species is most similar to L. melampyroides R. Knuth in Engler with which it shares such features as the plants densely strigillose, leaves subglabrous adaxially, and flowers that are usually solitary in axils of upper leaves. However, the new species differs from L. melampyroides by the succulent leaves, the creeping or drooping stems $15-25 \mathrm{~cm}$ long, and the suborbicular to broadly elliptic corolla lobes. A morphological comparison between the new species and L. melampyroides is presented in Table 1.

\section{Phylogenetic position}

The aligned lengths of ITS are 655 bp with gaps treated as missing data. BI and ML analyses produced similar topology and only the BI tree was presented in Figure 1.

Table I. Morphological comparison between Lysimachia xiangxiensis sp. nov. and its similar species.

\begin{tabular}{l|c|c}
\hline \multicolumn{1}{c|}{ Character } & L. xiangxiensis sp. nov. & L. melampyroides \\
\hline Stems & creeping or drooping. & erect or ascending. \\
\hline Plant height & $15-25 \mathrm{~cm}$ & $15-50 \mathrm{~cm}$ \\
\hline Petiole & not auriculate at base & dilated and auriculate at base \\
\hline Blades of lower leaves & pucculent, rhomboid-ovate to ovate, the basal 1 or 2 & papery, ovate to linear-lanceolate \\
& pairs scale-like & papery, ovate to linear-lanceolate, \\
Blades of upper leaves & succulent, ovate to elliptic-lanceolate, $2-5.5 \mathrm{~cm} \times$ & $1.5-9 \times 0.3-2.5 \mathrm{~cm}$ \\
\hline Secondary veins & $1-2.3 \mathrm{~cm}$ & visible on both surfaces \\
& blurry or invisible on adaxial surface, slightly raising on & \\
\hline Glandular dots on leaves & abaxial surface & transparent, sparse \\
\hline Corolla lobes & Absent & obovate-elliptic, apex rounded, $6-7 \times 4-6 \mathrm{~mm}$ \\
& suborbicular to broadly elliptic, apex cuspidate or \\
\hline Calyx lobes & emarginated, $7-9$ mm long and wide & costa distinct \\
\hline
\end{tabular}




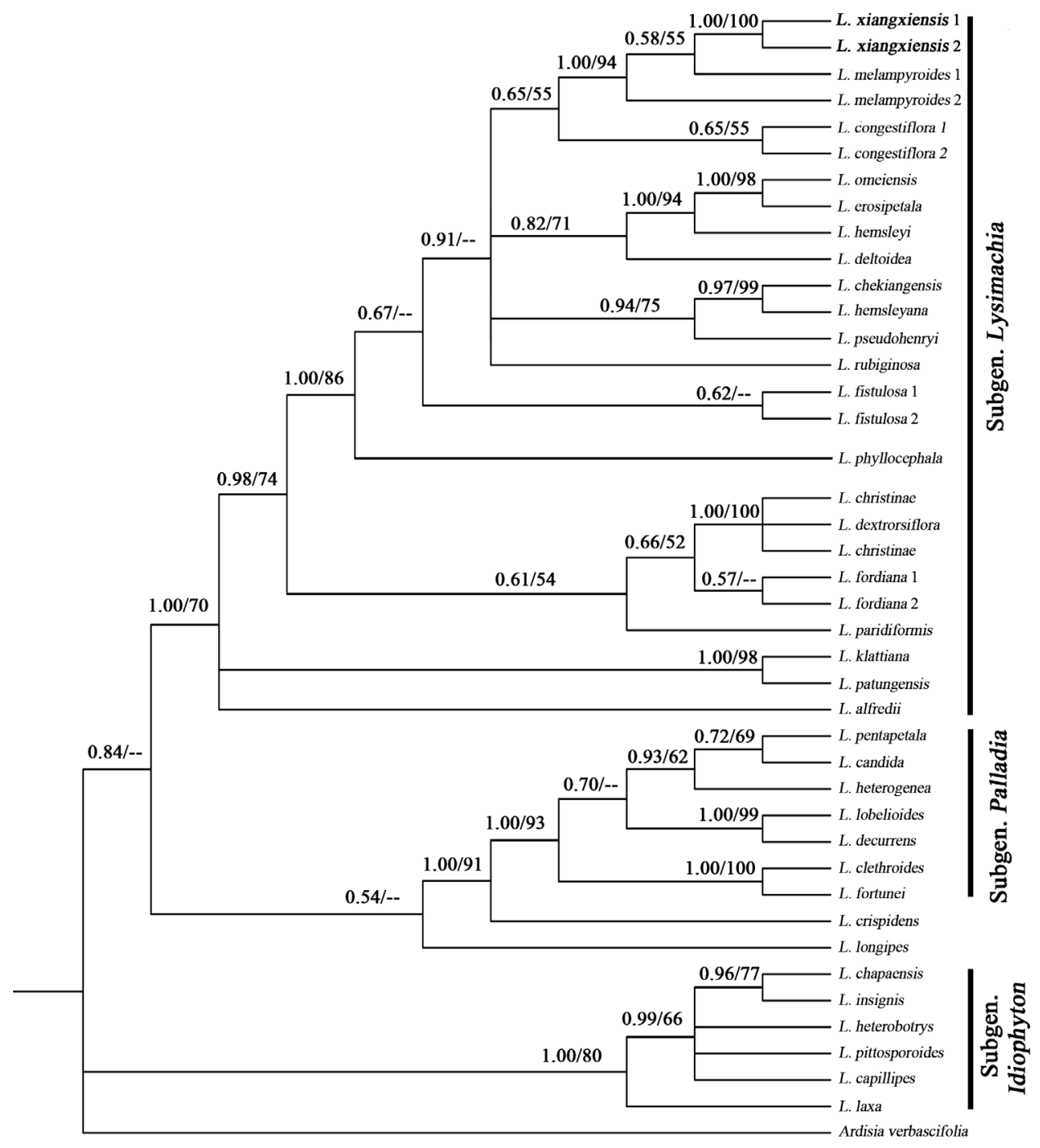

Figure I. The phylogram of Bayesian inference (BI) tree from the ITS sequence data, showing the phylogenetic position of Lysimachia xiangxiensis sp. nov. (shown in bold). Values above the branches represent Bayesian posterior probabilities (PP) and bootstrap values (LP) for maximum likelihood, respectively; the dash (-) indicates $\mathrm{LP}<50 \%$.

The phylogenetic results indicate that two samples of the new species were grouped together with a strong support $(\mathrm{PP}=1.00, \mathrm{LP}=100 \%)$ and closely related to L. melampyroides $(\mathrm{PP}=1.00, \mathrm{LP}=94 \%)$.

On the basis of the classification in Handel-Mazzetti (1928), Chen and Hu (1979) divided the genus into five subgenera as well as many series, Subgen. Lysimachia, Subgen. Palladia (Moench) Hand.-Mazz, Subgen. Idiophyton Hand. -Mazz., Subgen. Naumburgia (Moench) Klatt and Subgen. Heterostylandra (Hand.-Mazz.) Chen et C. 
M. Hu. In this topology, all Lysimachia species form three main clades: Subgen. Lysimachia $(\mathrm{PP}=1.00, \mathrm{LP}=70 \%)$, Subgen. Palladia $(\mathrm{PP}=1.00, \mathrm{LP}=93 \%)$ and Subgen. Idiophyton. ( $\mathrm{PP}=1.00, \mathrm{LP}=80 \%)$. In addition, L. crispidens (Hance) Hemsley in $\mathrm{F} . \mathrm{B}$. Forbes \& Hemsley of Subgen. Heterostylandra is close to Subgen. Palladia (PP $=1.00$, $\mathrm{LP}=91 \%)$ and L. longipes Hemsley is assigned to Subgen. Lysimachia with weak supported $(\mathrm{PP}=0.54)$ in a neutral position between Subgen. Lysimachia and L. crispidens. But classification of series are not well reflected in this analysis.

\section{Taxonomic treatment}

\section{Lysimachia xiangxiensis D.G.Zhang \& C.Mou, Y.Wu, sp. nov.} urn:Isid:ipni.org:names:77206205-1

Figure 2-4

Type. CHINA. Hunan Province, Huayuan County, Buchou Town, Da-long-dong, cliff of a valley, $28^{\circ} 19^{\prime} 06.42 \mathrm{~N}, 109^{\circ} 30^{\prime} 03.22 " \mathrm{E}$, alt. $295 \mathrm{~m}, 26$ August 2019, D. G. Zhang 0826075 (holotype: JIU!; isotype: JIU!).

Diagnosis. The new species differs from L. melampyroides by the succulent leaves; the creeping or drooping stems $(15-25 \mathrm{~cm}$ long); and the suborbicular to broadly elliptic corolla lobes.

Description. Terrestrial, perennial herbs. Rhizome brown, reduced to a small tuber or rarely creeping, with sparse fibrous roots. Stems creeping or drooping on cliffs, 15$25 \mathrm{~cm}$ long, clustered, branched at base, unbranched or rarely branched from the middle, terete, purple-red, densely strigillose, the internodes usually 3-7 cm long. Leaves petiolate, opposite. Petioles 5-7 mm long, with a furrow on adaxial side, green or purple-red, strigillose. Leaf blade succulent; blade of lower leaves rhomboid-ovate to ovate, with 1 or 2 pairs of basal leaves scalelike (much smaller); blade of upper leaves ovate to elliptic-lanceolate, $2-5.5 \mathrm{~cm} \times 1-2.3 \mathrm{~cm}$, base cuneate, apex acuminate or acute to subobtuse, margin entire and revolute, adaxially dark green, shiny, subglabrous, abaxially
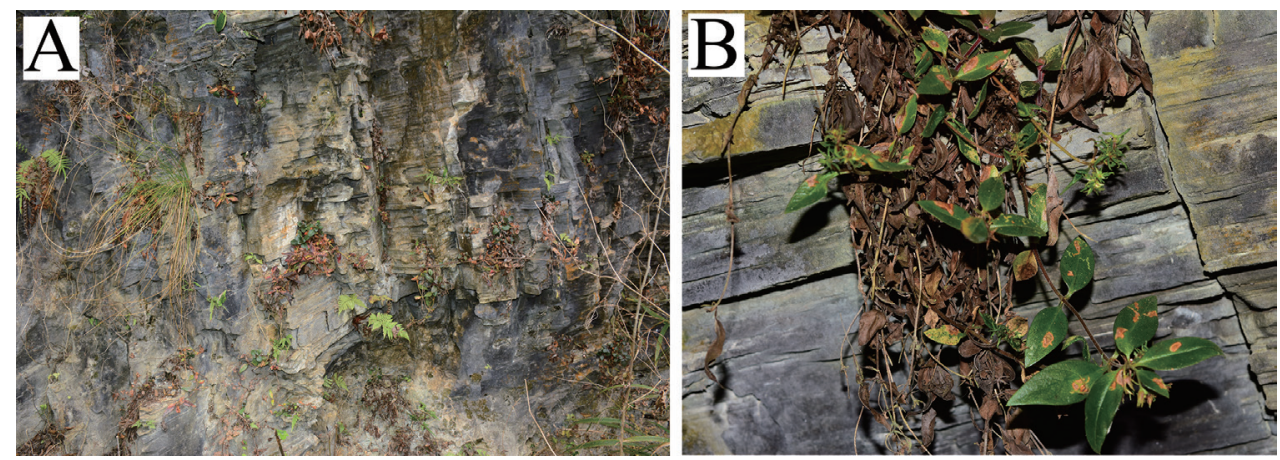

Figure 2. Lysimachia xiangxiensis sp. nov. in the wild A habitat (dry limestone cliff) B stems drooping on the cliff. 

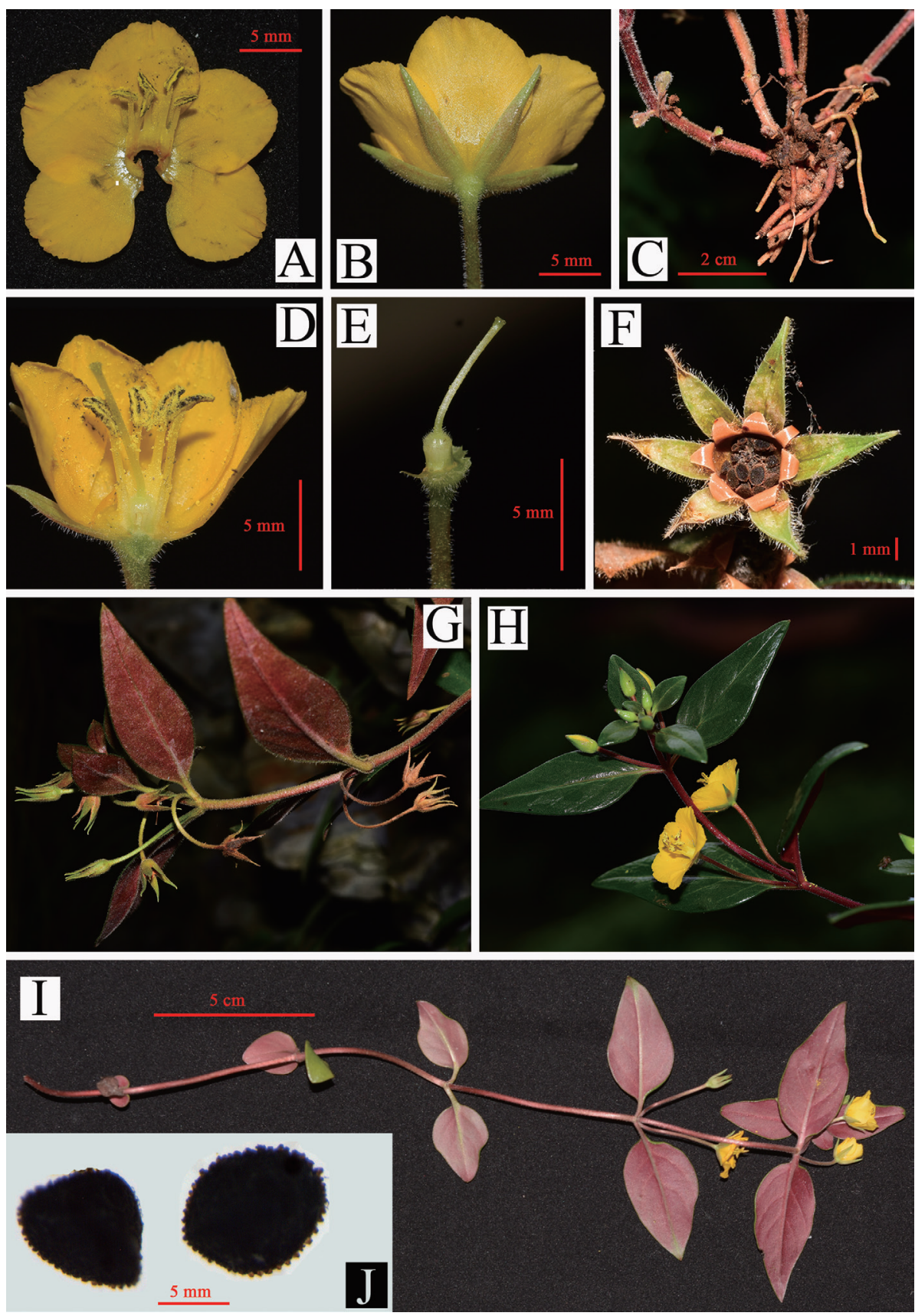

Figure 3. Lysimachia xiangxiensis sp. nov. in the field $\mathbf{A}$ corolla opened, showing the suborbicular lobes B flower (lateral view), showing the lanceolate calyx lobes indistinctly costate $\mathbf{C}$ proximal stems and underground part, showing stems clustered, rhizome, sparse fibrous roots, and 1 or 2 pairs of scalelike basal leaves $\mathbf{D}$ longitudinal section of flower, showing filaments connate basally into a tube $\mathbf{E}$ pistil, showing strigillose hairs on apex of ovary and base of style $\mathbf{F}$ dehiscent capsule $\mathbf{G}$ plant in fruiting, showing the recurved pedicels $\mathbf{H}$ plant in flowering, showing the solitary flowers in axils of upper leaves $\mathbf{I}$ plant in flowering, showing the reduced basal leaves $\mathbf{J}$ papillate seeds 


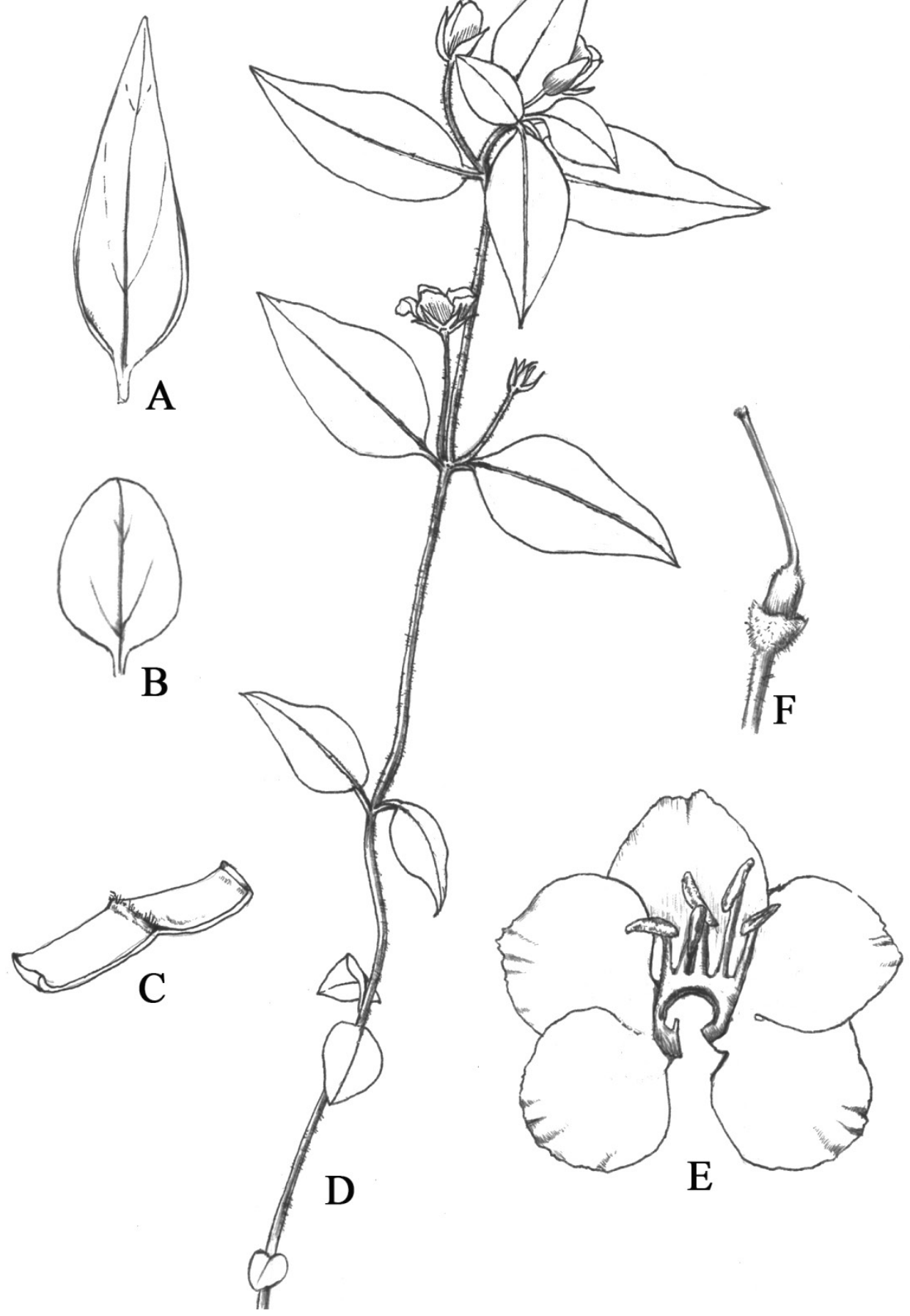

Figure 4. Lysimachia xiangxiensis sp. nov. A upper stem leaf (abaxial surface), showing revolute margins B lower stem leaf (adaxial surface) $\mathbf{C}$ portion of a leaf (abaxial surface), showing the revolute margins and strigillose midrib $\mathbf{D}$ plant in flowering $\mathbf{E}$ corolla lobes $\mathbf{F}$ pistil. 
purple-red (in arid places) or light green (in moist places), densely strigillose along the midrib, not glandular on both surfaces; secondary veins 3-4 pairs, blurry or invisible adaxially, slightly raising abaxially, veinlets invisible. Flowers bisexually, solitary in axils of upper leaves, occasionally in terminal racemes with bractlike leaves. Pedicels 1.5-3 $\mathrm{cm}$ long, gradually reduced toward stem apex, purple-red or light purple-red, densely strigillose, recurved in fruit. Calyx lobes 5, rarely 6, persistent, lanceolate with indistinct costa, 6-8 $\mathrm{mm} \times 1.5-2 \mathrm{~mm}$, apex acuminate-subulate, inside glabrous and with 3-4 veins, outside purple-red or green, densely strigillose. Corolla yellow, tube 1-2 mm long, actinomorphic, contorted; lobes 5, 7-9 $\mathrm{mm} \times 7-9 \mathrm{~mm}$, suborbicular to broadly elliptic, apex cuspidate or rounded, erose above the middle. Stamens 5, yellow, opposite to corolla lobes; filaments connate basally into a tube ca. $2.5 \mathrm{~mm}$ high, free parts 3.5-4.5 mm; anthers ca. $2 \mathrm{~mm}$ long, dorsifixed, opening by lateral slits. Style ca. $6 \mathrm{~mm}$ long, apex slightly expanded, strigillose on lower part. Ovary cylindrical, ca. $1.5 \mathrm{~cm}$ in diam., strigillose on apex, superior. Capsule brown, subglobose, 3-4 $\mathrm{mm}$ in diam., densely strigillose, dehiscing by valves. Seeds small, black, angular, papillate.

Phenology. Flowering May-June, fruiting July-August.

Distribution and habitat. This new species is currently known from Huayuan County and Jishou City in western Hunan Province, central China. It usually grows on limestone cliffs in valleys (Figure 2), and is associated with e.g. Eriophorum comosum (Wallich) Nees in Wight, Pteris vittata Linnaeus, Pteris deltodon Baker, and Dryopteris sp.

Etymology. The specific epithet "xiangxiensis", literally meaning western Hunan, refers to the Xiangxi Tujia and Miao Autonomous Prefecture in central China, to which Huayuan County and Jishou City belong. The Chinese name of the Lysimachia xiangxiensis is xiang xi guo lu huang in Pinyin.

Conservation status. Lysimachia xiangxiensis usually grows on limestone cliffs in valleys so we suggest its placement in the Data Deficient category of IUCN (2017)

Additional collection. CHINA. Hunan Province, Jishou City, Aizhai Town, National Forest Park, cliff of a valley, 31 May 2019, Y. Wu 0531001(paratype, JIU!).

\section{Acknowledgments}

This work was supported by STS Program of the Chinese Academy of Sciences (No. KFJ-3W-No1) and the Traditional Chinese Medicine Public Health Special Project ([2017] 66). We thank Dr Wannachai Chatan for their thoughtful review of our submitted paper .

\section{References}

APG III (2009) An update of the angiosperm phylogeny group classification for the orders and families of flowering plants: APG III - Botanical Journal of the Linnean Society 161(2): 105-121. https://doi.org/10.1111/j.1095-8339.2009.00996.x 
Burnham KP, Anderson DR (2003) Model Selection and Multimodel Inference: a Practical Information-theoretic Approach, Second Edition. Springer-Verlag, New York, 347.

Chen FH, Hu CM (1979) Taxonomic and phytogeographic studies on Chinese species of Lysimachia. Acta Phytotax Sinica 17(4): 21-53.

Chen FH, Hu CM, Fang YI, Cheng CZ (1989) Primulaceae. In: Chen FH, Hu CM (Eds) Flora Reipublicae Popularis Sinicae 59. Science Press, Beijing, 3-133

Doyle JJ, Doyle JD (1987) A rapid DNA isolation procedure for small quantities of fresh leaf tissue. Phytochemical bulletin, botanical Society of America 19: 11-15.

Handel-Mazzetti H (1928) A revision of the Chinese species of Lysimachia. Notes from the Royal Botanic Garden Edinburgh 16: 51-122.

Hu CM, Kelso S (1996) Primulaceae. In: Wu ZY, Raven PH (Eds) Flora of China 15. Science Press, Beijing and Missouri Botanical Garden Press, St Louis, 39-189

Huelsenbeck JP, Ronquist F (2001) MRBAYES: Bayesian inference of phylogenetic trees. Bioinformatics 17(8): 754-755. https://doi.org/10.1093/bioinformatics/17.8.754

IUCN (2017) Guidelines for using the IUCN red list categories and criteria. Version 13. Prepared by the Standards and Petitions Subcommittee. https://www.iucnredlist.org/resources/redlistguidelines

Liu K, Hong X, Zhou SB, Cheng YS, Tang CF, Xu HJ (2014a) A new species of Lysimachia (Myrsinaceae) from Dabieshan Mountain, China. Plant Systematics and Evolution 300(7): 1615-1620. https://doi.org/10.1007/s00606-014-0986-Z

Liu K, Zhou SB, Chen YS, Hong X (2014b) Lysimachia dabieshanensis sp. nov. (Primulaceae), a new species from Dabieshan Mountain, China. Phytotaxa 174(2): 119-122. https://doi. org/10.11646/phytotaxa.174.2.8

Nylander JAA (2004) MrModeltest v2. Program distributed by the author. Evolutionary Biology Centre, Uppsala University, 2.

Stamatakis A (2006) RAxML-VI-HPC: Maximum likelihood-based phylogenetic analyses with thousands of taxa and mixed models. Bioinformatics (Oxford, England) 22(21): 26882690. https://doi.org/10.1093/bioinformatics/btl446

Swofford DL (2002) PAUP*: Phylogenetic Analysis Using Parsimony (*and other methods), version 4.0. Sinauer Associates, Sunderland, Massachusetts, 142.

Wang Y, Ma W, Zhou SB, Liu K (2018) Lysimachia tianmaensis (primulaceae), a new species from Anhui, China. PhytoKeys 98: 117-124. https://doi.org/10.3897/phytokeys.98.23751

Yan HF, Hao G (2012) Lysimachia huchimingii sp. nov. (Primulaceae) from China. Nordic Journal of Botany 30(4): 443-445. https://doi.org/10.1111/j.1756-1051.2012.01401.x

Yan HF, Xu Y, Zhu ZM, Hu CM, Hao G (2017) Lysimachia sinopilosa (Primulaceae), a new species from Yunnan, China. Annales Botanici Fennici 54(1-3): 45-48. https://doi. org/10.5735/085.054.0308

Zhang CY, Wang FY, Yan HF, Hao G, Hu CM, Ge XJ (2011) Testing DNA barcoding in closely related groups of Lysimachia L. (Myrsinaceae). Molecular Ecology Resources 12(1): 98-108. https://doi.org/10.1111/j.1755-0998.2011.03076.x

Zhou JJ, Yu XL, Deng YF, Yan HF, Lin ZL (2015) Lysimachia huangsangensis (Primulaceae), a new species from Hunan, China. PLoS One 10(7): 1-13. https://doi.org/10.1371/journal. pone. 0132713 


\section{Appendix}

Appendix SI. Accessions of the genus Lysimachia L. examined in this study.

\begin{tabular}{|c|c|c|c|}
\hline Taxon & $\begin{array}{l}\text { GenBank } \\
\text { Acc. No. }\end{array}$ & Voucher & Locality \\
\hline L. alfredii Hance & JN638405 & Hao394 & Lianping, Guangdong, China \\
\hline L. candida Lindley & JF976885 & Ge2010001 & Yangchun, Guangdong, China \\
\hline L. capillipes Hemsley in F. B. Forbes \& Hemsley & JF976886 & Y2009200 & Jiujiang, Jiangxi, China \\
\hline L. chapaensis Merrill & JF976888 & GBOWS878 & Hekou, Yunnan, China \\
\hline L. chekiangensis C. C. Wu & JF976891 & Y2009263-1 & Longquan, Zhejiang, China \\
\hline \multirow[t]{2}{*}{ L. christiniae Hance } & JF976894 & Y2009244 & Lin'an, Zhejiang, China \\
\hline & JF976896 & Y2009209 & Jiujiang, Jiangxi, China \\
\hline L. clethroides Duby in A. de Candolle & JF976899 & Y2009157 & Tongbai, Henan, China \\
\hline \multirow[t]{2}{*}{ L. congestiflora Hemsley in F. B. Forbes \& Hemsley } & JF976902 & GBOWS262 & Malipo, Yunnan, China \\
\hline & JF976903 & Y2009266 & Longquan, Zhejiang, China \\
\hline L. crispidens (Hance) Hemsley in F. B. Forbes \& Hemsley & JF976906 & Hao212 & Yichang, Hubei, China \\
\hline L. decurrens $\mathrm{G}$. Forster & JF976908 & GBOWS1234 & Hekou, Yunnan, China \\
\hline L. deltoidea Wight & JF976909 & GLM081121 & Zhongdian, Yunnan, China \\
\hline L. dextrosiflora X. P. Zhang, X. H. Guo \& J. W. Shao & JF976913 & Y2009265-1 & Longquan, Zhejiang, China \\
\hline L. erosipetala F. H. Chen \& C. M. Hu & JF976914 & Y2010037-2 & Emeishan, Sichuan, China \\
\hline \multirow[t]{4}{*}{ L. fistulosa Handel-Mazzetti } & JF976916 & Ning20101 & Jinggangshan, Jiangxi, China \\
\hline & JF976917 & Ye et al. 3561 & Lianshan, Guangdong, China \\
\hline & JF976919 & Y2009285 & Ruyuan, Guangdong, China \\
\hline & JF976920 & Ye et al. 3940 & Lianshan, Guangdong, China \\
\hline L. fortune Maximowicz & JF976925 & Y2009195 & Jinggangshan, Jiangxi, China \\
\hline L. hemsleyana Maximowicz ex Oliver & JF976932 & Guo20001 & Ningguo, Anhui, China \\
\hline L. hemsleyi Franchet & JF976935 & Hao713 & Huili, Sichuan, China \\
\hline L. heterobotrys F. H. Chen \& C. M. Hu & JF976936 & Y2010053-2 & Ningming, Guangxi, China \\
\hline L. heterogenea Klatt & JF976939 & Y2009199 & Jiujiang, Jiangxi, China \\
\hline L. insignis Hemsley & JF976945 & Hao245 & Napo, Guangxi, China \\
\hline L. klattiana Hance & JF976947 & Y2010014-1 & Tongbai, Henan, China \\
\hline L. laxa Baudo & JF976949 & Han longran6 & Puer, Yunnan, China \\
\hline L. lobelioides Wallich in Roxburgh & JF976951 & Hao303 & Menglian, Yunnan, China \\
\hline L. longipes Hemsley & JF976952 & Guo xinhu200012 & Shitai, Anhui, China \\
\hline \multirow[t]{2}{*}{ L. melampyroides R. Knuth in Engler } & JF976955 & Dengyunfei 15945 & Xinning, Hunan, China \\
\hline & JF976956 & Lichanghan 8174 & Shangzhi, Hunan, China \\
\hline L. omeiensis Hemsley & JF976958 & Y2010033 & Emeishan, Sichuan, China \\
\hline L. paridiformis Franchet & JF976962 & Y2010044 & Emeishan, Sichuan, China \\
\hline L. patungensis Handel-Mazzetti & JF976964 & Ye et al. 3851 & Lianshan, Guangdong, China \\
\hline L. pentapetala Bunge & JN638407 & Y2010013-1 & Tongbai, Henan, China \\
\hline L. phyllocephala Handel-Mazzetti & JF976969 & Y2010030 & Emeishan, Sichuan, China \\
\hline L. pittosporoides C. Y. Wu & JF976970 & Hao248 & Malipo, Yunnan, China \\
\hline L. rubiginosa Hemsley in F. B. Forbes \& Hemsley & JF976972 & Hao419 & Dujiangyan, Sichuan, China \\
\hline \multirow{2}{*}{$\begin{array}{l}\text { Lysimachia xiangxiensis D.G.Zhang \& C.Mou, Y.Wu, } \\
\text { sp. nov. }\end{array}$} & MN647745 & Y. Wu 0531001 & Jishou, Hunan, China \\
\hline & MN647744 & D. G. Zhang 0826075 & Huayuan, Hunan, China \\
\hline Ardisia verbascifolia $\mathrm{Mez}$ & JN638408 & GBOWS1216 & Hekou, Yunnan, China \\
\hline
\end{tabular}

